\title{
The Impact of Corporate Reputation in a Dairy Company
}

\section{Maria da Graça Casimiro Almeida* and Arnaldo Matos Coelho}

School of Economics, University of Coimbra, Portugal

\begin{abstract}
The purpose of this paper is to understand the importance of corporate reputation (CR) how main intangible asset of a company. This study investigates the role of CR on optical three group's stakeholders: cooperants, workers and customers on loyalty in cooperative organizations. This study proposes a theoretical model tested using structural equation modeling. 1200 valid questionnaires were collected from a three group samples: cooperants; workers and customers of the biggest dairy union of cooperatives in Iberia. CR has a significant impact on loyalty in three group's stakeholders on organizations cooperatives. Corporate reputation is revealed as an intangible asset, constituting, as the pillar of organizational development by providing ability to compete in the market and generate profits. This study is based on three cross-sectional data from a dairy company. This is a topic that, given the multiplicity of possible approaches, it is even less studied the theoretical level as regards the analysis of corporate reputation with applicability in the various organizational stakeholders. The results give new guidelines to redress the cooperatives traditional management, namely the management of intangible assets like reputation. This paper contributes to the competitiveness of a type of organization closed to the social structure of the rural population. This research with three types of stakeholders (cooperants, customers and workers) power shall be constituted as an important contribution to the literature, for what has been analyzed only works strand of customers (external) and/or employees (internal). The results bring the management challenges of the $21^{\text {st }}$ century to the traditional principles underlying cooperatives management helping them to reinforce competitiveness. The intangibility is always a difficult area of research, in which old doors close and new doors open.
\end{abstract}

Keywords: Corporate reputation; Communication; Image; Loyalty; Stakeholders

\section{Introduction}

Currently organizations face new circumstances and changes due to the complexity, dynamism and uncertainty associated with globalization [1]. The study of stakeholders has been a key area of interest in the management literature over the last 25 years [2], either academic or professional. These have sought to understand the expectations and needs of stakeholders and their categorization in management groups $[3,4]$. According to authors it is necessary for organizations to develop long-term relationships with stakeholders [5,6].

Recently, however, scholars have questioned approaches that view predominantly stakeholders from the perspective of organizations or, in other words, the groups that should be managed for organizational gain rather than existing in genuinely mutually dependent relations $[7,8]$. However, such a view is contrary to Freeman's [9] which emphasize the interdependency of organization and stakeholders. Applying the resource-based view (RBV) organizations must understand what resources are available to them and leverage their business creating strategic advantages, since they are key resources to be utilized in conjunction with monetary reserves and physical infrastructure $[10,11]$. The various groups of stakeholders are increasingly interested in the destinations of organizations wanting to take part in decisions affecting the future of organizations. Thus, the performance of these companies has been seen with attention to the needs of these groups, seeking improvements in innovation to respond to the new challenges they face. Technological progress, market volatility, higher consumer demand, the trend towards corporate concentration, are profound and rapid changes, that have arisen related to globalization, which requires greater attention from managers. All these changes mean a sharp increase in competition at the international level, more open competitive environment. Companies to survive the changes have to adopt new forms of management in the organization [12]. Companies for these reasons, have to meet these groups with developments in all fields: institutional, financial, human resources and management, especially $[13,14]$. The stakeholder theory seems to be a good answer to this complexity that organizations are living, seeking to ensure the continuity of business. This theory attempts to model reality and offer solutions to overcome the situations [15].

\section{Materials and Methods}

\section{Corporate reputation}

A company's reputation is widely recognized as a key intangible asset, one that has been argued corporate reputation reflects the level of credibility, reliability and trustworthiness that an organization has with its stakeholders [16-19]. Corporate reputation is a perception built up over time, and based on the company's corporate identity, projected corporate images, business performance, and how corporate actions are aligned with stakeholder concerns [20,21]. Corporate reputation has been considered as the most valuable intangible resource that firms can have and so can influence value creation and profit and the potential to generate sustainable competitive advantages and to improve the intrinsic value of a firm [22-29]. Fombrun [30] proposes a definition of reputation which comprises four components (1) collective assessments of a (2) company's attractiveness for a (3) set of stakeholders, compared to a (4) reference group or company.

*Corresponding author: Maria da Graça Casimiro Almeida, School of Economics, University of Coimbra, Portugal, Tel: + 351239859 900; E-mail: graca.casimiro@hotmail.com

Received July 16, 2017; Accepted October 06, 2017; Published October 13, 2017

Citation: Almeida MGC, Coelho AM (2017) The Impact of Corporate Reputation in a Dairy Company. Bus Eco J 8: 320. doi: 10.4172/2151-6219.1000320

Copyright: (C) 2017 Almeida MGC, et al. This is an open-access article distributed under the terms of the Creative Commons Attribution License, which permits unrestricted use, distribution, and reproduction in any medium, provided the original author and source are credited. 
As proposed by Roig et al. [31], the reputation of a firm and its products and services play an important role in creating a desirable value for its stakeholders. A good corporate reputation confers several marketing advantages, including the ability to command price premiums in the market, to form favorable relationships with supply chain partners, to maintain competitive product positioning, and to generate greater customer loyalty [32,33]. For marketing managers, the primary external stakeholders are customers, but other individuals, groups, or organizations can have an impact on decisions related to marketing strategy formulation and implementation. These include suppliers, vendors, distributors, dealers, retailers, investors, employees, shareholders, consumer groups, and community activists.

The overall reputation of a company combines judgments about different facets of corporate behaviors interacting with various stakeholder groups in activities in the labor markets, capital markets, or product markets $[22,34,35]$. In line to Argenti and Drucken Miller [20] reputation is an outcome of interactions between stakeholders and the organization over time.

\section{Stakeholder theory}

According to Jones and Wicks [36] and Savage et al. [37], the basic premises of stakeholder theory are: the organization enters into relationships with many groups that influence or are influenced by the company, i.e., "stakeholders" in accordance with Freeman's [9] terminology; the theory focuses on the nature of these relationships in terms of processes and results for the company and for stakeholders; the interests of all legitimate stakeholders are of intrinsic value and it is assumed that there is the prevailing single set of interests.

Van Riel [38] and Donaldson and Preston [39] pointed out that the theory focuses upon management decision making. Stakeholder theory can be considered as an innovation in how to manage the company and allow mitigating conflicts between the parties (market, religion and marketers) that make up the organisation. In addition, it connects stakeholders to ensure the creation of value and success in the markets [40-43]. The real reason for belonging to the company is to create sustained value by meeting human needs and economic benefit. To this end, the stakeholder theory is very important for the organization to face successfully the markets because the stakeholders are increasingly more demanding, so you can change the organization if they are not satisfied. Thus, companies should recognize, incorporate the ideas and suggestions provided by stakeholders. Resources and capacity generated by the cooperation of each stakeholder group are considered the basis for the creation of competitive advantages $[9,44,45]$.

Stakeholder theory is a comprehensive view of companies, trying to strike a balance between the stakeholders of the company, with the aim of adapting to the continuous changes that occur in the environment, taking into account the continuity. It is important to know how to reconcile all interests and awaken each flow for each group, in achieving the overall objectives of the company, so that the credibility of the stakeholders and the good organizational image are the vehicle to achieve business success $[45,46]$.

Organizations, to enhance the reputation, should guide social marketing to its stakeholders identifying their objectives, prejudices and signs on the legitimacy of the company's shares [47]. Joint decisions among stakeholders and the organization reinforce the sense of corporate responsibility and therefore the reputation through ethical and sustainable behavior [48,49]. All stakeholders, such as customers, suppliers, distributors, investors, and community groups, assess corporate reputation over time through image and publicity campaigns, and actual experience with products and services [50].

Companies are implementing social responsibility practices in response to pressure from increasingly sensitive stakeholders to the social and environmental aspects of the company and that a response to competitive pressure. CSR is a means for companies to differentiate themselves from competitors, to promote a positive image of the company through the formulation of autonomous commitments, improve corporate reputation and create a climate of trust between the company and stakeholders. Postel and Rousseau [51] report that the business conduct should incorporate the need to moralize stakeholders of social enterprise and environmental, consequences of business activities (workers). The theory of stakeholders is considered the benchmark theory for the analysis of reputation. Associated with this theory there is the concept of stakeholders that refers to "all individuals or groups of individuals who influence or are influenced by the activities of the company" [52].

Donaldson and Preston [39] distinguish between three main approaches to analyzing stakeholders namely the descriptive approach, the instrumental approach and normative approach. The descriptive approach proposed to explain the functioning of the management process and how managers work in the organisation, taking into account the interests and demands of the different actors. The instrumental approach seeks to identify possible links between management based on consideration of the stakeholders and organizational performance. In this sense the companies that create relations of cooperation and trust with its stakeholders are at a competitive advantage over those that do not, especially in terms of opportunity cost or prevention. The regulatory approach is based on concepts and principles that justify the moral and philosophical consideration of stakeholder interests. The combination of descriptive and instrumental approach reflects an empirical reflection of stakeholder theory, they represent tools for strategic management, whereas the normative approach introduces an ethical vision of strategic management. Therefore, it should encourage the control of a relationship of trust and cooperation with stakeholders and integration of their interests and concerns into corporate strategies and business $[41,44,53]$.

The management implements principles, processes and their impact on stakeholder groups for guidance in the various activities of the companies in order to balance the interests of stakeholders and improve business reputation. In addition, the principles also demonstrate the company's commitment to meet the expectations and standards required by stakeholders [54,55]. For cases, these may involve activities such as: the generation of information about stakeholders, their expectations and perceptions of the organization; the development of initiatives consistent with the principles of reorganization and designed to meet the demands of stakeholders and even anticipate their future demands and evaluation of the organisation's impacts on the social issues raised by stakeholders. In short, the goal is to manage and develop lasting relationships with various groups of stakeholders by meeting their needs and expectations [56]. It is the engagement of stakeholders in this process that gives it legitimacy $[7,57]$.

\section{Models bi}

Based on Freeman [9] original terminology, the prospect of organizations can be seen as "stakeholders affect an organisation", while the prospect of stakeholders can be seen as "stakeholders are affected by organisations." Then come the bi-directionality notion to bridge this gap [58]. 
A bi-directional approach helps to map the specific nature and causal of key issues within the organization relationship/stakeholder and does so in a way that can be rigorously tested. The bidirectional takes into account the needs and expectations that organizations have from stakeholders and these are the organisations, thriving sense of reciprocity and balance perceived and fairness in terms of trade $[59,60]$. This usually includes anything of value company's offer to stakeholders and stakeholders offer something of value to the organization [61]. Reputation is active important for stakeholders, namely for workers and members of cooperative, but their role is crucial to the organization's reputation [62,63]. "Report framework" and "report process" can be adapted and applied to different situations to achieve mutually rewarding and harmonious exchanges between organizations and stakeholders in line with the vision of many stakeholder theorists [64].

\section{Communication}

Corporate communication is defined as 'the overall planning, execution and evaluation of an organization's communication with stakeholders groups that affect the ability and goals of an organization [65]. According to Duncan and Moriarty [66], communication is a human activity that connects individuals and creates relationships. Sincerity, transparency and consistency form the trinomial developed by Halderen and Riel [67] to characterize the communication elements that can impact upon a company's reputation. Corporate communication is a core element used by corporate marketers to communicate with specific stakeholders. Communication allows companies to align their own interests with stakeholders' interests or to create a favorable basis to interact with their different stakeholders [68]. According to Goodman and Hirsch [69] is used to describe a variety of functions of strategic management and may play a decisive role in the behavior and success of the organization $[47,70]$. Depending on the organisation, corporate communication may include: public relations; the emergency communication crisis; corporate citizenship; reputation management; community relations; relations with the media; investor relations; relations between employees; government relations; the marketing communication; communications management; corporate brand, image building and advertising. A good strategic approach the communication can to be a key to a business success [35]. Omar et al. [71] argue that companies should consider the importance of internal and external communication, ensuring complete control of communication with all kinds of stakeholders [20,72]. Lovelock et al. [73] suggest that effective communication becomes possible to provide satisfactory services and the maintenance of harmonious and productive relationships, strengthening the trust, respect and loyalty of stakeholders. Communication and reputation are closely interconnected. Their importance can hardly be overestimated; they are critical in the process of positioning of an organization [74]. Corporate communication and behaviour contribute to creating and maintaining a solid, sustainable, unambiguous reputation [75]. According to Van Riel and Fombrun [76]; Zerfass [77]; Hawabhay et al. [78] corporate communication plays a crucial role in the process of reputation development by listening to publics expectations, addressing them with planned flows of communication content and cultivating relationships with the most salient stakeholders. When the role of corporate communication function within organizations beyond the perception of influential stakeholders for the formation of organizational reality, committing stakeholders making more sustainable reputation, being one of their antecedents [79]. Gradually, communication is important for building CR and the implementation of a corporate communication strategy positively influences the efficiency and effectiveness, reinforces the values that represent the organization culture as well as its essence and the brand, along with behaviors and symbolism $[20,80]$. The role and importance of corporate communications which are incorporated throughout all marketing management positions reflected in the creation and strengthening of the corporate image in the operations and performance of enterprises in the market $[68,81]$.

\section{Therefore, the following hypothesis has been formulated:}

H1: Communication has a positive and significant impact on CR.

Corporate image is defined as the "general impression" that remains in the minds of stakeholders as a result of the accumulated feelings, ideas, attitudes and experiences with the organization, when the organization's name is brought to mind [82-86]. Corporate image is a result of communication process in which the organizations create and spread a specific message that reflects their core values that they believe [86-88]. This is in line with study by Keller's [89] worldwide vision of brand image. Thus, corporate image could be considered as a type of brand image in which the brand name refers to the organization as a whole rather than to its sole products/services. The importance of corporate communication to build, protect and maintain corporate reputation has been advocated in numerous publications in recent years. Reputation and information sharing represent signals that stakeholders observe in the process of value creation, which is seen as the end focus for corporate [90]. Usually, image is considered the measure of effectiveness of corporate communication.

The role of corporate communications is to project a good and consistent image of the organization across multiple audiences [91]. Both corporate communication and image provide a potential route for competitive advantage for the organization [38,92].

Therefore, the following hypothesis has been formulated:

H2: Communication has a positive and significant impact on Image.

Communication with stakeholders is essential for developing loyalty. The form of the communications is very important [93]. Amine et al. [94] argue that communication, satisfaction and loyalty are mechanisms that provide an ethical and socially responsible climate, since participating in the enhancement of quality in relations between the company and the different stakeholders. Indeed, communication contributes to the dissemination of information on ethical activities and socially responsible company supporting the creation of relations of trust and commitment between the company and its stakeholders, and therefore your satisfaction and loyalty. Thus, the implementation of a corporate communication strategy positively influences the efficiency and effectiveness of the organization and its reputation. Gotsi and Wilson [95] emphasized the role of communication in creating reputation, maintaining that organizational reputation is a stakeholder's overall evaluation of a company based on the stakeholder's direct experiences with the company and any other model of communication. The management recognizes the fact that keeping their existing customers is just as important as creating new ones, and loyalty marketing has become vital to its success [96]. Loyalty programs is marketing strategies develop to increase stakeholder's loyalty [97]. However, not all loyalty programs perform effectively, and many companies struggle due to unsuccessful loyalty programs, and to maintaining loyalty requires an equal and continuous balance of three components: process, value and communication. Communication may both enhance the loyalty and perceived benefits and still invoke a sense of community through the quality of information and the communication style [98-100]. 
Therefore, the following hypothesis has been formulated:

H3: Communication has a positive and significant impact on Loyalty.

\section{Reputation and image}

Nguyen and Leblanc [101] defined corporate image as a subjective knowledge, or attitude such as ideology, corporate name, reputation and delivery system quality level. Corporate image is defined as the "overall impression" in the stakeholders' mind as a result of accumulative feelings, ideas, attitudes and experiences with the organisation, stored in memory, transformed into a positive/negative meaning, retrieved to reconstruct image when the name of the organization is heard or brought the public $[82,84-86,102]$. Corporate image is a multi-dimensional construct [103]. Today, it is commonly agreed that a strong and distinctive corporate image is the key to sustainable competitive advantage [104,105].

Kennedy [106] and Gotsi and Wilson [95] emphasize the importance of stakeholders as communicators and the impact they have on strengthening the corporate image. Corporate image has two sides, namely, organizational and individual [107]. For stakeholders, the corporation's appeal and reputation develop several images from sources, including stakeholders' perceptions, attitudes and emotions [108-110]. Dowling [111] demonstrates that corporate image is the result of aligning organizations themselves with their stakeholders' perceptions through communication efforts [112].

The distinction between CR and image is not always clear; neither is the nature of the reciprocal impacts $[113,114]$. Nguyen and Leblanc [115] argue that, due to the meaning of the constructs CR and corporate image, it is acceptable to suggest that $\mathrm{CR}$ has an impact on corporate image. However, Brown et al. [21] show that corporate image seems to have a broader scope combining the company's expectation of how it is to be seen based on the construed external image [68], while $\mathrm{CR}$ is formed by the perceptions of external stakeholders. Corporate image and reputation are considered critical to the overall assessment of any organization due to the idea underlying the perception and the stakeholders' feelings when hearing the organization's name [82,85,86,116-118]. Fares et al. [119] show how image and reputation are important elements for the development and maintenance of loyal and satisfying relationships with stakeholders.

So, the following hypothesis is formulated:

H4: CR has a positive and significant impact on Image.

\section{Reputation and loyalty}

Walsh and Beatty [120] noted that a firm's reputation is based on a favorable general estimation of the organization by the public. As a result, a firm's reputation could impact positively on the public's attitudes and behaviors towards the organisation. Many researchers refer to corporate reputations as intangible assets and resources that can contribute to a firm's competitive advantage [121-123], however, the favorable image is viewed as a critical aspect of a company's ability to maintain its market position. The reputation of a firm may be interpreted as the overall perception of a company, what it stands for, what it is associated with, and what one may be supposed to gain when buying its products or using its services [124-126]. The perceived reputation is subjective interpretation of reality, which is obtained by an individual and affects cognitive attitude and affective or emotional aspects [127]. The overall reputation of an organization combines judgments about different corporate attitudes interacting with stakeholder groups (activities in the labor markets, capital and product markets) [34]. These corporate attitudes and actions send different stakeholders the value of reputation of organizations [128].

Organizations wishing to build stakeholder loyalty need to consider the experiences of stakeholders when they interact with the corporate brand. Stakeholders, as customers, are exposed to many brand-related stimuli including brand identifying colours, shapes, typefaces, background design elements, slogans, brand characters, packaging, marketing communications, and the environment in which the brand is sold [129]. These are linked with four dimensions of brand experience: sensory, affective, behavioral, and intellectual. Loyalty is fundamental to the success of a cooperative organization, its members being the vital part of the organization and loyalty the way to its success [130]. In the literature, loyalty has been defined as an attitude and as a behavior [131].

The loyalty can be manifested in multiple ways, such as by expressing a preference for a company over others, by continuing to purchase from it, or by increasing business with it in the future [132]. The satisfaction is thought to be an important antecedent of loyalty [133]. Kim et al. [134] also found support for the relationship between satisfaction and loyalty, and Chang et al. [135] concluded that satisfaction is positively related to loyalty. Chun [136] has argued that the reputation might be related to loyalty, and that satisfaction and loyalty may be either antecedents or consequences of reputation.

Many studies in the corporate reputation literature show that a good reputation positively affects a firm's performance and stakeholders loyalty [125,137]. Chiou and Droge [138] showed that loyalty can be increased through the stakeholders's perceived reputation in a business. Andreassen [139] modeled a relationship between reputation and loyalty and concluded that reputation may be the strongest driver of loyalty in the public sector. Authors like Marzo-Navarro et al. [140]; Helgesen and Nesset [141] show a positive link between reputation and loyalty based on research among university students. According to Loureiro and Kastenholz [133] demonstrated the positive effect of the company's reputation on loyalty. Weiwei [113] emphasized the importance given by researchers to reputation and corporate image as being the most important factors in building loyalty.

Accordingly, the following hypothesis is formulated:

H5: CR has a positive and significant impact on Loyalty.

\section{Image and loyalty}

Keller [89] defines image as perceptions about a company held in consumer memory. According to Nguyen and Leblanc [110], corporate image is related to business name, architecture, variety of products/services, tradition, ideology and to the impression of quality communicated by each person interacting with firm's stakeholders. The loyalty is determined by image $[142,143]$. However, the relationship between image and loyalty is not clear since several studies have failed to demonstrate the direct impact of image on customer loyalty [144,145] Authors as Andreassen and Lindestad [146] and Wu et al. [147] argue that in complex and infrequently used services, brand image rather than satisfaction may be the main predictor of loyalty. The relationship between image and loyalty has brought differing results: while Sirgy and Samli [148] report a direct relationship among image and store loyalty, the findings of Bloemer and Ruyter [149] in the banking industry indicate an indirect relationship where the influence of image is mediated by service quality. In tourism Kandampully and Suhartanto [150] found image to be one of the two most important factors for 
guests of a hotel to consider repurchase and recommendation. Bigné et al. [151] found that image impacts simultaneously on all three components, namely perceived quality, satisfaction and loyalty.

Previous empirical research supports a positive link between corporate image and loyalty [146,149,152,153]. Selnes [137] also confirmed the influence of corporate brand image on brand loyalty. However, Davies and Chun [145] found that corporate brand image had an indirect influence on brand loyalty via customer satisfaction when personality traits are used to portray corporate brand image in an off-line setting. Helm [154] studied loyalty as a two-dimensional construct, namely affective loyalty and loyalty behavior. Individuals act according to an affective predisposition, so affective loyalty can be viewed as an antecedent of behavior loyalty. Weiwei [113] emphasizes the importance given by researchers to $\mathrm{CR}$ and corporate image as the most important factors in loyalty building. Akroush et al. [155] in study's find a relationship image has positively and significantly affected destination loyalty with those international tourists on Jordan.

So, the following hypothesis is formulated:

H6: Image has a positive and significant impact on Loyalty.

\section{Conceptual model}

The proposed model presents the set of hypotheses developed. Corporate reputation produces interest to the various stakeholders and the model presented is adjusted to the 3 groups of stakeholders (Figure 1).

\section{Method}

\section{Sample and data collection}

The research universe for this study comprised the members of three cooperatives, shareholders in the biggest dairy company in the Iberian Peninsula. Data were collected through a survey applied all over the country. In order to test the proposed investigation model and the research hypotheses, data was collected via structured questionnaires to each group stakeholders. The data collection has a total of 1200 valid responses (464 consumers; 263 cooperants; 473 workers) and in the period of January 2, 2014 and June 5, 2014.

The sample comprises 50,8\% men and 49,2\% women. Respondents are $25 \%$ aged between 18 and 30 years, $45.1 \%$ between 31 and 45 years and $29.9 \%$ between 46 and 60 years. Concerning the level of education, the majority has the secondary level $35.8 \%$ and $43 \%$ have graduation and the remainder has 1 cycle.

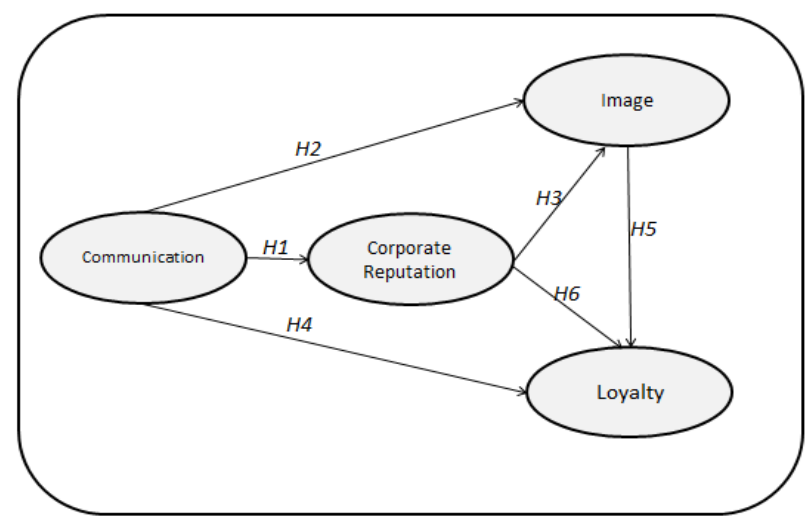

Source: Author's own research.

Figure 1: Conceptual Model.

\section{Measures}

In order to operationalise the variables, we conducted a literature review and adapted scales used in previous investigations.

A Likert-type scale ranging from 1 (disagree strongly) to 7 (strongly agree) was used to measure the constructs CR, image, communication, and loyalty. Loyalty metrics are not the same but are comparable in their content.

Communication was operationalised according to Riel [156] Thomaz and Brito [81]. The scale was made up of five items such as "I trust in the data on products and services". After a confirmatory factor analysis the final Cronbach's alpha was 0.90 .

CR scale was based on Walsh et al. [157], and treated the construct as multi-dimensional. The measure had five sub-scales, as follows: customer orientation, good employer, reliable and financially strong company, product and service quality, and social and environmental responsibility. A total of 28 items were defined. Items such as "Has management who seems to pay attention to the needs of its employees"; "Develops innovative services" and "Is environmentally responsible" were used. The final test presented a Cronbach's alpha coefficient between 0.87 and 0.94 .

Image was operationalized according to the study by Nguyen and Leblanc [115]. The scale was made up of three items such as "I believe that this organization has a better image than its competitors". The final test presented a Cronbach's alpha coefficient of 0.86 .

Loyalty was operationalized according to Helm [154]. The scale was made up composed of four items such as: "are you going to hold your shares on a long term basis?" The final test presented a Cronbach's alpha coefficient of 0.92 .

\section{Common method bias}

When self-administered questionnaires are used, a common variance bias problem can emerge or increase [158]. According to Podsakoff et al. [158], the common method variance (CMV) tests help to identify the existence of variables that can cause measurement errors and systematic bias in the estimation of the relationships between constructs. The emergence of this problem may arise when a) the information about the independent and dependent variables comes from the same respondent, $b$ ) the same scale format is used throughout the questionnaire and c) different constructs are measured at the same time and using the same instrument. Proceeded to single Harmans factor test, which is, according Podsakoff and Organ [159], the most commonly used method in the literature in general and in marketing research. According to this proposal, if there's a single factor analysis or general factor accounting for over $50 \%$ of the variance of the variables, the common method bias will be present, but in this study, a single factor explains $38.25 \%$ of the variance of the variables, then not checks the bias of the method.

\section{Reliability and validity}

In order to perform descriptive statistics, correlations, and exploratory factor analysis, the researchers used the statistic software IBM SPSS 19.0 Statistical package. Amos 19.0 was used to perform CFA (confirmatory factor analysis) and SEM (structural equation modeling). Initially, CFA was conducted to test the measurement model and the psychometric properties of the scales used [160]. All items are measured on a seven-point Likert scale ( $1=$ strongly disagree to $7=$ strongly agree). CFA was used to assess the psychometric properties of the scales and 
the measurement model fit, using AMOS 19. The final model shows a good fit (IFI=0.969; TLI=0.962; CFI=0.969; RMSEA=0.048; CMIN/ $\mathrm{DF}=3.769 ; \mathrm{GFI}=0.943$ ) (Appendix).

Item-total correlations are all above 0.50 and the a values on Table 1 are all above 0.90. Average Variance Extracted (AVE) values are between 0.7 and 0.9 . The measures used seem to be reliable according to Hair [160]. All the correlations between constructs are significantly below 1 and all the squared multiple correlations are smaller than the AVE.

The discriminant validity of the constructs was tested. It is assumed that the correlation between the different constructs theoretically is low. Discriminant validity is evidenced by the fact that all correlations between the constructs are significantly smaller than 1 and the squared correlations calculated for each pair of constructs is always smaller than the variance extracted for correspondent constructs, thereby confirming the discriminant validity (Table 1) $[161,162]$.

\section{Findings}

The results of the multigroup show that in general there are no major differences. There are 6 hypotheses in which five of them were supported. Hypothesis 4 is shown as unsupported.

We then used SEM to test the proposed hypotheses, revealing that the adjustment measures are appropriate and show good levels. The final structural model shows a good fit (IFI=0.956; TLI=0.950; CFI $=0.955 ; \quad$ RMSEA $=0.052 ; \quad C M I N / D F=4.198 ; \quad G F I=0.907) . \quad$ Table 2 presents the results for the structural model. A global analysis was performed to identify the differences between the three stakeholders group.

And as a result we confirmed the statistical significance of all positive relationships, except the hypothesis 4 , which despite significant is the proposed reverse. To the 2 groups of stakeholders (workers; cooperants) as well as reverse also appears not significant $(\mathrm{H} 4)$.

Communication has a significant and positively impact on CR in the 3 groups stakeholders, therefore $H 1$ is supported. This result is in line with studies $[38,68,163]$. Communication appears to be crucial for reputation.
Communication has a positively and significantly impacts on corporate image in global study, except the group of cooperants, supporting H2. These results are similar to those $[88,164]$. Communication is very important but customers should be the main target. Cooperants appear to be less touched by communication maybe because they are both customers and suppliers [62].

$\mathrm{CR}$ has a positive impact on image, therefore $\mathrm{H} 3$ is supported. This result corroborates the conclusions $[62,88,114]$. Reputation seems to be crucial for cooperants (srw $=0.790)$ which are the main recipients for a reputation policy. Workers to $(\mathrm{srw}=0.475)$, they seem to be influenced by the organization reputation. Finally, customers present the lowest impact ( $\mathrm{srw}=0.333$ ) perhaps because communication is more evident and more impacting.

The construct communication is not significantly related on loyalty, therefore not support for H4. This result is similar for the three groups of stakeholders. Communication is a very important variable, however, on what concerns loyalty, the skepticism seems to prevail [165-168]. Moreover, even if not significant, the coefficients are negative which increases the idea of that potential skepticism, with the exception of customers.

Image is positively related to loyalty for the overall study and for each of the 3 study groups of stakeholders, therefore $H 5$ is supported. This result corroborates the conclusions [113].

CR is positively related to loyalty for the overall study and for each of the 3 study groups of stakeholders, therefore $H 6$ is supported. This result corroborates the conclusions $[113,154]$.

\section{Conclusions}

The objectives this research intends to propose and test a model that identifies the formation of corporate reputation and assesses their impacts, from the perceptions of three groups of stakeholders: cooperants, workers and customers, namely the impact on loyalty in cooperative organisations.

The methodology this study proposes a theoretical model tested using structural equation modeling. For this purpose, 1200 valid questionnaires were collected from a research sample comprised of

\begin{tabular}{|c|c|c|c|c|c|c|c|c|c|c|c|}
\hline & SD & $\mathbf{X 1}$ & $\mathrm{X} 2$ & $\mathrm{X3}$ & $\mathrm{X} 4$ & $\mathrm{X5}$ & $\mathrm{X} 6$ & $\mathrm{X} 7$ & $\mathbf{X 8}$ & CC & AVE \\
\hline Rep O Customer (X1) & 0.9235 & 0.938 & - & - & - & - & - & - & - & 0.9097 & 0.7165 \\
\hline Rep Good Empl (X2) & 0.9004 & 0.560 & 0.929 & - & - & - & - & - & - & 0.8876 & 0.7249 \\
\hline Rep Reab Financ (X3) & 0.8774 & 0.545 & 0.584 & 0.937 & - & - & - & - & - & 0.8984 & 0.6891 \\
\hline Rep Qual (X4) & 0.8555 & 0.480 & 0.448 & 0.472 & 0.881 & - & - & - & - & 0.8637 & 0.6791 \\
\hline Rep Soc Env Resp (X5) & 0.9089 & 0.539 & 0.519 & 0.538 & 0.489 & 0.870 & - & - & - & 0.8999 & 0.6701 \\
\hline Imag (X6) & 0.7978 & 0.379 & 0.407 & 0.454 & 0.348 & 0.401 & 0.862 & - & - & 0.9021 & 0.7548 \\
\hline Communicat (X7) & 0.8103 & 0.445 & 0.422 & 0.475 & 0.362 & 0.430 & 0.460 & 0.904 & - & 0.8585 & 0.6707 \\
\hline Loyalty (X8) & 10.510 & 0.595 & 0.642 & 0.640 & 0.509 & 0.641 & 0.636 & 0.524 & 0.915 & 0.8666 & 0.6197 \\
\hline
\end{tabular}

Obs: The principal diagonal presents Cronbach's Alpha; SD: Standard Deviation; CC: Composite reliability; VE: Variance extracted.

Table 1: Standard deviation; Correlations, Cronbach's Alpha, compose reliability and variance extracted.

\begin{tabular}{|c|c|c|c|c|c|c|c|c|c|c|}
\hline & \multirow[b]{2}{*}{ Relationships } & \multicolumn{2}{|c|}{ GLOBAL n= 1200} & \multicolumn{2}{|c|}{ Workers $n=473$} & \multicolumn{2}{|c|}{ Consumers $n=464$} & \multicolumn{2}{|c|}{ Cooperants $n=263$} & \\
\hline & & SWR & $P<0.001$ & SWR & $P<0.001$ & SWR & $P<0.001$ & SWR & $P<0.001$ & \\
\hline $\mathrm{H} 1$ & Comunic------->Reput & 0.703 & - & 0.732 & - & 0.652 & - & 0.870 & - & Supported \\
\hline $\mathrm{H} 2$ & Comunic------->Imag & 0.308 & - & 0.143 & 0.024 & 0.505 & - & 0.030 & 0.396 & Supported \\
\hline H3 & Reput------->Imag & 0.449 & - & 0.475 & - & 0.333 & - & 0.790 & - & Supported \\
\hline $\mathrm{H} 4$ & Comunic-------> Loyalt & 0.104 & 0.003 & 0.095 & 0.076 & 0.006 & 0.466 & 0.054 & 0.317 & Not Supported \\
\hline $\mathrm{H} 5$ & Imag------->Loyalt & 0.319 & - & 0.393 & - & 0.344 & - & 0.380 & - & Supported \\
\hline $\mathrm{H} 6$ & Reput------>>Loyalt & 0.63 & - & 0.573 & - & 0.517 & - & 0.475 & - & Supported \\
\hline
\end{tabular}

Table 2: Results structural model. 
three group stakeholders: cooperants; workers and customers of the biggest union of dairy cooperatives of the Iberian Península.

The results are based on a cross-sectional study, cemented the stakeholders of a "union of cooperatives" of the dairy sector, the Iberian leader in the production, processing and marketing of dairy products.

The research shows that the communication relations with the reputation and image are significant, which leads us to conclude that stakeholders attach importance to the way the organization communicates its strategies, products and services. To emphasize the crucial role of communication in building a good business reputation, and a connecting link between the stakeholders - based on attributes: Sincerity, Transparency and Consistency. The relation between on corporate reputation and loyalty also it presents significant, so that we can complete the sense of belonging of stakeholders with the organisation, as trust and how much they are satisfied with the organisation's management practices and attitudes. The relationships between communication and loyalty seem marginally significant, which implies that managers must join forces to realize the behaviors and needs of its stakeholders, improving their strategies.

The results of this research are very important for managers, as they may define their strategies and allocate its resources in activities that contribute to the construction of its reputation and still reveal how an intangible asset may become crucial for the improvement of relations with the stakeholders, relation to the performance and competitiveness.

\section{Contribution}

The row of milk is considered as an important segment of the national agricultural industry and the role developed by cooperatives is fundamental for the consolidation and strengthening of the sector. Cooperatives are an important mark for the mobilization of milk producers, leading to its modernization and restructuring and contributing to the competitiveness of a type of organisation closed to the social structure of the rural population. This is all-important, since we are dealing with subject sector instability for political reasons and or climate, thus serving as suitable barometer to check the "weight" of reputation in the organisation. This this can be a sign of differentiation in the market and source of competitive advantage.

The overall results are conclusive and contribute to a better understanding of CR, within the 3 groups of stakeholders or the global level or at the individual level. These findings are of great importance to both scholars and managers, since, the corporate reputation is a multidimensional concept that has attracted the attention over time. Managing CR is a difficult procedure a dynamic process which calls for increased efforts, even to maintain the levels achieved. It is presented as a major concern for managers worldwide and strategically managed at the highest corporate level. It is known as one of the most important intangible assets of a company and should be considered as a source of competitive advantage, with positive and differentiating consequences.

This paper contributes to the literature concerning cooperatives, and specifically to the issue of competitiveness within this type of organization closed. The investigation's conclusions confirm the influence of $\mathrm{CR}$ on image and loyalty. The results show that a change in the cooperatives' management practices, based on CR, and supportive strong and visible CSR practices, would help to reinforce the competitiveness of the cooperatives, as these practices would bring them closer to the overall managerial practices, typically used in companies from the most dynamic sectors.
This analysis aims to innovate to investigate the phenomenon of corporate reputation from the point of view of the three main groups of stakeholders in relation to a large Portuguese organization of the cooperative sector: cooperates; workers and customers.

The investigation in the cooperatives field is relevant and recommended due to the importance of the sector and to the attraction they represent. Cooperatives usually lack of managerial skills to face globalization and competitiveness. A new generation of cooperatives is looking for a place in a market characterized by aggressive strategies, adding more value to their offers. According to several different companies are finding in the cooperative form a way to reinforce their resistance to closure and unemployment, an alternative to the actual competitiveness framework and a way to ensure the workers commitment and loyalty and a shared vision. Cooperatives may represent the right balance between individual objectives from specific stakeholders and survival and competitiveness.

\section{Limitations and Future Investigations}

This investigation is based on cross sectional data. When causal relationships are to be investigated, longitudinal data may help in the understanding that causality.

This research is based on a sample of 3 groups the stakeholders (workers; customers and cooperants) from a union of cooperatives from the dairy industry. However, it could be extended and applied to other organizations and other industries in order to compare results. Additionally, measures adopted may not fit equal among different stakeholders.

The development of a multidimensional scale with good psychometric properties and capable of capturing the CR assessment from different groups of stakeholders, and of assuring some comparability of the may be an excellent opportunity for future investigations.

\section{Conclusion and Concluding Remarks}

This research highlights the importance of intangible assets such as reputation management. Corporate reputation has received growing attention in recent decades. Opportunities for managers and executives to use the results as a means of boosting the competitiveness of their companies are revealed by the results of the study. In this respect, the study's findings are very important for managers, as they may help them formulate their strategies and allocate resources to activities that contribute to the construction of a strong reputation.

According to the strategic decisions surrounding the socially responsible behavior of a company may become a source of competitive advantage; thus, managers and owners have the opportunity to take advantage of that which the development of CSR practices provides on organisations. These practices on CR, can assist the companies in designing or modify social responsibility strategies used by the firm in order to build a positive CR .

The survey results reveal how an intangible asset may become crucial for the improvement of relations with the stakeholders, with respect to financial performance and competitiveness. The results can be concluded that corporate reputation can contribute to the overall performance of the company and is comparable between the various stakeholder groups.

Finally it is hoped that the results of this investigation can help companies from the cooperative sector to change their traditional 
management practices and principles and to achieve a greater convergence with more modern management approaches that are aimed at meeting the challenges facing organisations, nowadays.

\section{References}

1. Christmann P, Taylor G (2001) Globalization and the environment Determinants of firm self-regulation in China. Journal of International Business Studies 32: 439-458.

2. Laplume AO, Sonpar K, Litz RA (2008) Stakeholder theory: Reviewing a theory that moves us. Journal of Management 34: 1152-1189.

3. Mitchell RK, Agle BR, Wood DJ (1997) Towards a theory of stakeholder identification and salience: defining the principle of who and what really counts. Academy of Management Review 22: 853-886.

4. Jones TM, Felps W, Bigley GA (2007) Ethical theory and stakeholder-related decisions: The role of stakeholder culture. Academy of Management Review 32: 137-155

5. Doh JP, Guay TR (2006) Corporate social responsibility, public policy, and NGO activism in Europe and the United States: an institutional-stakeholder perspective. Journal of Management Studies 43: 47-73.

6. Pajunen K (2006) Stakeholder influences in organizational survival. Journal of Management Studies 43: 1261-1288.

7. Waddock S (2003) Stakeholder performance implications of corporate responsibility. International Journal of Business Performance Management 5 : $114-124$

8. Steurer R (2006) Mapping stakeholder theory anew: from the 'stakeholde theory of the firm' to three perspectives on business-society relations. Business Strategy and the Environment 15: 55-69.

9. Freeman RE (1984) Strategic Management: A stakeholder approach. Boston Pitman.

10. Nahapiet J, Ghoshal S (1998) Social capital, intellectual capital, and the organizational advantage. Academy of Management Review 23: 242-266.

11. Barney JB (2002) Strategic management: From informed conversation to academic discipline. The Academy of Management Executive 16: 53-57.

12. Carbonell $P$, Rodriguez $\mathrm{Al}$ (2006) The impact of market characteristics and innovation speed on perceptions of positional advantage and new product performance. International Journal of Research in Marketing 23: 1-12.

13. Carroll A (1991) The pyramid of corporate social responsibility: toward the moral management of organizational stakeholders. Future Ethos and Corporate Social Responsibility of Business 5: 225-235

14. Ali R, Lynch R, Melewar TC, Jin Z (2015) The moderating influences on the relationship of corporate reputation with its antecedents and consequences: $A$ meta-analytic review. Journal of Business Research 68: 1105-1117.

15. Reynolds SJ, Schultz FC, Hekman DR (2006) Stakeholder theory and managerial decision-making: Constraints and implications of balancing stakeholder interests. Journal of Business Ethics 64: 285-301.

16. Caruana A (1997) Corporate reputation: concept and measurement. Journal of Product \& Brand Management 6: 109-118.

17. Christiansen JK, Vendelø MT (2003) The role of reputation building in international R\&D project collaboration. Corporate Reputation Review 5: 304-329.

18. Timothy CW, Holladay SJ (2006) Unpacking the halo effect: Reputation and crisis management. Journal of Communication Management 10: 123-137.

19. Casalo LV, Flavia'n C, Guinalı'u M (2007) The influence of satisfaction, perceived reputation and trust on a consumer's commitment to a website. Journal of Marketing Communications 13: 1-17.

20. Argenti PA, Drucken Miller B (2004) Reputation and the Corporate Brand Corporate Reputation Review 6: 368-374.

21. Brown TJ, Dacin PA, Pratt MG, Whetten DA (2006) Identity, intended image construed image, and reputation: an interdisciplinary framework and suggested terminology. Academy of Marketing Science Journal 34: 99-106.

22. Fombrun CJ, Gardberg NA, Sever JM (2000) The Reputation Quotient SM A multi-stakeholder measure of corporate reputation. Journal of Brand Management 7: 241-255.
23. De la Fuente Sabaté JM, De Quevedo Puente E (2003) Empirical analysis of the relationship between corporate reputation and financial performance: A survey of the literature. Corporate Reputation Review 6: 161-177.

24. Wessels C (2003) Reputation defined. CSR Magazine 2: 28-29.

25. Borraz J, Fuentelsaz L (2005) La Gestión del Ciclo de Vida de las Capacidades: Un Análisis para el Caso de la Reputación. IV Iberoamerican Academy of Management, Lisboa.

26. De Quevedo Puente E, De la Fuente Sabaté JM, Delgado García JB (2005) Reputación corporativa y creación de valor. Marco teórico de una relación circular. Investigaciones Europeas de Dirección y Economía de la Empresa 11: 81-97.

27. Dowling G (2006) How Good Corporate Reputations Create Corporate Value Corporate Reputation Review 9: 134-143.

28. López VA (2006) An alternative methodology for testing a resource-based view linking intangible resources and long-term performance. Irish Journal of Management 27: 49 .

29. Cifuentes IO, León IMM (2011) Medida de la reputación empresarial en pymes de servicios. Revista Europea de Dirección y Economía de la Empresa 20: 77.

30. Fombrun $\mathrm{Cl}$ (2012) Corporate reputation: Definitions, antecedents, consequences. The Oxford Handbook of Corporate Reputation, pp: 94-113.

31. Roig JCF, Garcia JS, Tena MAM, Monzonis JL (2006) Customer perceived value in banking services. International Journal of Bank Marketing 24: 266-283.

32. Cretu AE, Brodie RJ (2007) The influence of brand image and company reputation where manufacturers market to small firms: a customer value perspective. Industrial Marketing Management 36: 230-240.

33. Balmer JMT (2011) Corporate marketing myopia and the inexorable rise of a corporate marketing logic: perspectives from identity-based views of the firm European Journal of Marketing 45: 1329-1352.

34. Helm S, Garnefeld I, Tolsdorf J (2009) Perceived Corporate Reputation and Consumer Satisfaction: An Experimental Exploration of Causal Relationships. Australasian Marketing Journal 17: 69-74.

35. Argenti P, Forman J (2004) The power of corporate communication: Crafting the voice and image of your business. Corporate Reputation Review 7: 96-98.

36. Jones TM, Wicks AC (1999) Convergent stakeholder theory. Academy of Management Review 24: 206-221.

37. Savage GT, Bunn MD, Gray B, Xiao Q, Wang S, et al. (2010) Stakeholde collaboration: Implications for stakeholder theory and practice. Journal of Business Ethics 96: 21-26.

38. Van Riel C (1995) Principles of Corporate Comunication. Academic Service Prentice Hall. London.

39. Donaldson T, Preston LE (1995) The stakeholder theory of the corporation: Concepts, evidence, and implications. Academy of Management Review 20 65-91.

40. Postrel V (2003) The Substance of Style: How the Rise of aesthetic Value is remaking commerce, Culture \& Consciousness, New York.

41. Fassin $Y$ (2008) Imperfections and shortcomings of the stakeholder model's graphical representation. Journal of Business Ethics 80: 879-888.

42. Dickinson-Delaporte S, Beverland M, Lindgreen A (2010) Building corporate reputation with stakeholders: Exploring the role of message ambiguity for social marketers. European Journal of Marketing 44: 1856-1874.

43. Mainardes WE, Alves $H$, Raposo M (2011) Stakeholder theory: issues to resolve. Management Decision 49: 226-252.

44. Freeman RE, Harrison JS, Wicks AC (2007) Managing for stakeholders: Survival, reputation, and success. Yale University Press.

45. Harrison JS, Bosse DA, Phillips RA (2010) Managing for stakeholders, stakeholder utility functions, and competitive advantage. Strategic Management Journal 31: 58-74.

46. Scott SG, Lane VR (2000) A stakeholder approach to organizational identity. Academy of Management Review 25: 43-62.

47. Goodman M (2010) The mirror of consumption: Celebritization, developmental consumption, and the shifting cultural politics of Fair Trade. Geoforum 41 104-116. 
48. Peloza J, Papania L (2008) The missing link between corporate social responsibility and financial performance: stakeholder salience and identification. Corporate Reputation Review 11: 169-181.

49. Koronis E, Ponis ST (2012) Introducing corporate reputation continuity to support organizational resilience against crises. Journal of Applied Business Research 28: 283-290

50. Simmons JA (2009) Both sides now': aligning external and internal branding for a socially responsible era. Marketing Intelligence \& Planning 27: 681-697.

51. Postel N, et Rousseau S (2008) RSE et éthique d'entreprise: la nécessité des institutions. Revue Management 11: 137-160.

52. Post JE, Preston LE, Sachs S (2002) Managing the extended enterprise: The new stakeholder view. California Management Review 45: 6-28.

53. Luoma-aho V, Vos M (2010) Towards a more dynamic stakeholder model: acknowledging multiple issue arenas. Corporate Communications: An International Journal 15: 315-331.

54. Maignan I, Ralston DA (2002) Corporate social responsibility in Europe and the US: Insights from businesses' self-presentations. Journal of International Business Studies 33: 497-514.

55. Banytè J, Gadeikienè A (2008) Corporate Social Responsibility as a marketing means in Luthuaniam business practice. Economics \& Management 13: 227-238.

56. Maignan I, Swaen V (2004) La responsabilité sociale d'une organisation intégration des perspectives marketing et managériale. Revue française du Marketing 200: 51-66.

57. Wood DJ, Logsdon JM, Lewellyn PG, Davenport K (2006) Global business citizenship: A transformative framework for ethics and sustainable capitalism. ME Sharpe.

58. Phillips RA, Johnson-Cramer ME (2006) Ties that Unwind: Dynamism in Integrative Social Contracts Theory. Journal of Business Ethics 68: 283-302.

59. Adams JS (1965) Inequity in social exchange. Advances in Experimental Social Psychology 2: 267-299.

60. Scott WR, Davis GF (2015) Organizations and organizing: Rational, natural and open systems perspectives. Routledge.

61. Peloza J, Shang J (2011) How can corporate social responsibility activities create value for stakeholders? A systematic review. Journal of the Academy of Marketing Science 39: 117-135.

62. Almeida MGC, Coelho A (2016) The role of corporate reputation on cooperants behavior and organizational performance. Journal of Management Development 35: 17-37.

63. Almeida MGC, Coelho AM (2015) The impact of Reputation in the performance of the Organization in the perspective of members of the cooperatives. Esic Market Economics and Business Journal 46: 9-36.

64. Money K, Hillenbrand C, Hunter I, Money AG (2012) Modelling bi-directional research: a fresh approach to stakeholder theory. Journal of Strategy and Management 5: 5-24

65. Steyn B, Puth G (2000) Corporate communication strategy. Heinemann Sandown.

66. Duncan T, Moriarty SE (1998) A communication-based marketing model for managing relationships. Journal of Marketing 56: 1-13.

67. Halderen MV, Van Riel C (2006) Developing a Corporate Expressiveness Mode for Managing Favorable Impressions Among Stakeholders. In: International Conference on Corporate Reputation.

68. Shamma HM (2012) Toward a comprehensive understanding of corporate reputation: Concept, measurement and implications. International Journal of Business and Management 7: 151-169.

69. Goodman MB, Hirsch PB (2010) Corporate Communication. Strategic Adaption for Global Practice, New York

70. Thiessen A, Ingenhoff D (2011) Safeguarding reputation through strategic integrated and situational crisis communication management: Development of the integrative model of crisis communication. Corporate Communications: An International Journal 16: 8-26.

71. Omar M, Jr RLW, Lingelbach D (2009) Global brand market-entry strategy to manage corporate reputation. Journal of Product \& Brand Management 18: $177-187$
72. Balmer JMT, Greyser SA (2006) Corporate marketing: Integrating corporate identity, corporate branding, corporate communications, corporate image and corporate reputation. European Journal of Marketing 40:730-741.

73. Lovelock C, Wirtz J, Lapert D, Munos A (2008) Marketing des services [Services marketing]. Paris: Pearson.

74. Karnaukhova NA, Polyanskaya EV (2016) Communication and reputation as essentials for the positioning of an organization. Al \& Society 31: 371-379.

75. Bosch van den ALM, de Jong MDT, Elving WJL (2005) How Corporate Visua Identity Supports Reputation. Corporate Communications: An International Journal 10: 108-116.

76. Van Riel CBM, Fombrun CJ (2007) Essentials of corporate communication Oxon: Routledge.

77. Zerfass A (2008) Corporate communication revisited: Integrating business strategy and strategic communication. In Public Relations Research, pp: 65-96.

78. Hawabhay BB, Abratt R, Peters M (2009) The role of corporate communications in developing a corporate brand image and reputation in Mauritius. Corporate Reputation Review 12: 3-20.

79. Romenti S (2010) Reputation and stakeholder engagement: an Italian case study. Journal of Communication Management 14: 306-318.

80. Gill R (2015) Why the PR strategy of storytelling improves employee engagement and adds value to CSR: An integrated literature review. Public Relations Review 41: 662-674.

81. Thomaz JC, Brito EPZ (2010) Corporate reputation: formative constructs and implications for management. Revista de Administração Contemporânea 14 229-250.

82. Fombrun CJ (1996) Reputation: Realizing Value from the Corporate Image. Harvard Business School Press.

83. Dowling GR (2001) Creating Corporate Reputations-Identity, Image and Performance. New York: Oxford University Press.

84. Kazoleas D, Kim Y, Moffitt MA (2001) Institutional image: a case study Corporate Communications: An International Journal 6: 205-216.

85. Hatch MJ, Schultz M, Williamson J (2003) Bringing the corporation into corporate branding. European Journal of Marketing 37: 1041-1064.

86. Bravo R, Montaner T, Pina JM (2009) The role of bank image for customers versus non-customers. International Journal of Bank Marketing 27: 315-334.

87. Leuthesser L, Kohli C (1997) Corporate identity: The role of mission statements Business Horizons 40: 59-66.

88. Van Riel C, Balmer J (1997) Corporate identity: the concept, its measurement and management. European Journal of Marketing 31: 340.

89. Keller KL (1993) Conceptualizing, measuring, and managing customer-based brand equity. The Journal of Marketing, pp: 1-22.

90. Žabkar V, Arslanagić-Kalajdžić M (2014) The impact of corporate reputation and information sharing on value creation for organizational customers. South East European Journal of Economics and Business 8: 42-52.

91. Christensen LT, Morsing M, Cheney G (2008) Corporate communications: Convention, complexity and critique. London: Sage Publications.

92. Mohamad B, Bakar HA, Halim H, Ismail AR (2014) Corporate Communication Management (CCM) and Organisational Performance: A Review of the Current Literature, Conceptual Model and Research Propositions. Procedia-Social and Behavioral Sciences 155: 115-122.

93. Smith AD, Rupp WT (2002) Communication and loyalty among knowledge workers: A resource of the firm theory view. Journal of Knowledge Management 6: 250-261.

94. Amine MEA, Chakor A, Alaoui AM (2012) Ethics, relationship marketing and corporate performance: Theoretical analysis through the mediating variables. International Business Research 5: 68.

95. Gotsi M, Wilson AM (2001) Corporate reputation: seeking a definition. Corporate Communications: An International Journal 6: 24-30.

96. Lam SY, Shankar V, Erramilli MK, Murthy B (2004) Customer value, satisfaction, loyalty, and switching costs: an illustration from a business-to-business service context. Journal of the Academy of Marketing Science 32: 293-311. 
97. Chai JC, Malhotra NK, Dash S (2015) The impact of relational bonding on intention and loyalty: the mediating role of commitment foci in service relationships. Journal of Hospitality and Tourism Technology 6: 203-227.

98. Barsky J, Nash L (2006) Companies update loyalty programs, increase effectiveness. Hotel \& Motel Management 22: 28-29.

99. Nunes JC, Drèze $X(2006)$ Your loyalty program is betraying you. Harvard Business Review 84: 124.

100. Berezan O, Yoo M, Christodoulidou N (2016) The impact of communication channels on communication style and information quality for hotel loyalty programs. Journal of Hospitality and Tourism Technology 7: 100-116.

101. Nguyen N, LeBlanc G (1998) The mediating role of corporate image on customers' retention decisions: an investigation in financial services. International Journal of Bank Marketing 16: 52-65.

102. Tran MA, Nguyen B, Melewar TC, Bodoh J (2015) Exploring the corporate image formation process. Qualitative Market Research: An International Journal 18: 86-114.

103. Spector AJ (1961) Basic dimensions of the corporate image. The Journal of Marketing, pp: 47-51.

104.Davies G (2003) Corporate reputation and competitiveness. London: Routledge.

105. Melewar TC, Karaosmanoglu E (2006) Seven dimensions of corporate identity: A categorisation from the practitioners' perspectives. European Journal of Marketing 40: 846-869.

106. Kennedy SH (1977) Nurturing corporate images: total communication or ego trip? European Journal of Marketing 11: 120-164.

107. Yeo RK, Goh M, Tso S (2011) Corporate image and reputation of large Mainland Chinese enterprises. Journal of Marketing Communications 17: 195211.

108. Grönroos C (1984) A service quality model and its marketing implications European Journal of Marketing 18: 36-44.

109. Karaosmanoglu E, Bas ABE, Zhang JK (2011) The role of other customer effect in corporate marketing image and consumer-company identification. European Journal of Marketing 45: 1416-1445.

110. Nguyen B, Melewar TC, Chen J (2013) The brand likeability effect: can firms make themselves more likeable? Journal of General Management 38: 25-50.

111. Dowling GR (1993) Developing Your Company Image into a Corporate Asset. Long Range Planning 26: 101-109.

112. Christensen TL, Askegaard S (2001) Corporate identity and corporate image revisited-A semiotic perspective. European Journal of Marketing 35: 292-315.

113. Weiwei $T$ (2007) Impact of Corporate Image and Corporate Reputation on Customer Loyalty: A Review. Management Science and Engineering 1: 57-62.

114. Podnar K, Tuškej U, Golob U (2012) Mapping semantic meaning of corporate reputation in global economic crisis context: A Slovenian study. Public Relations Review 38: 906-915

115. Nguyen N, Leblanc G (2001) Corporate image and corporate reputation in customers' retention decisions in services. Journal of Retailing and Consumer Services 8: 227-236.

116. Kandampully J, $\mathrm{Hu} \mathrm{H}$ (2007) Do hoteliers need to manage image to retain loyal customers. International Journal of Contemporary Hospitality Management 19: 435-443.

117. Sarstedt M, Wilczynski P, Melewar TC (2013) Measuring reputation in global markets: A comparison of reputation measures' convergent and criterion validities. Journal of World Business 48: 329-339.

118. Nguyen N (2006) The Perceived Image of Service Cooperatives: An Investigation in Canada and Mexico. Corporate Reputation Review 9: 62-78.

119. Fares D, Achour M, Kachkar O (2013) The Impact of Service Quality, Student Satisfaction, and University Reputation on Student Loyalty: A Case Study of International Students in IIUM, Malaysia. Information Management \& Business Review 5: 584-590.

120.Walsh G, Beatty SE (2007) Customer-based corporate reputation of a service firm: scale development and validation. Journal of the Academy of Marketing Science 35: 127-143.
121. Dowling GR, Staelin R (1994) A model of perceived risk and intended riskhandling activity. Journal of Consumer Research 21: 119-134.

122. Van Riel CB (1997) Research in Corporate Communication An Overview of an Emerging Field. Management Communication Quarterly 11: 288-309.

123. Barney JB (1991) Firm Resources and Sustained Competitive Advantage. Journal of Management 17: 99-120.

124. Weiss AM, Anderson E, MacInnis DJ (1999) Reputation management as a motivation for sales structure decisions. Journal of Marketing 63: 74-89.

125. MacMillan K, Money K, Downing S, Hillenbrand C (2005) Reputation in emotions and behaviours. Corporate Reputation relationships: measuring experiences. Review 8: 214-232.

126. Thomas RG (2011) U.S. Patent No. 7,890,627. Washington, DC: US Paten and Trademark Office.

127. Ranjbarian B (2006) Inferred image of Iran as a tourist destination. Journal of Isfahan University (Humanities) 2: 69-80.

128. Bartikowski B, Walsh G (2011) Investigating mediators between corporate reputation and customer citizenship behaviors. Journal Business Research 64: 39-44.

129. Brakus JJ, Schmitt BH, Zarantonello L (2009) Brand experience: what is it? How is it measured? Does it affect loyalty? Journal of Marketing 73: 52-68.

130.Bhuyan S (2007) The "People" Factor in Cooperatives: An Analysis of Members' Attitudes and Behavior. Canadian Journal of Agricultural Economics 55: $275-298$.

131.Ball D, Coelho SP, Machás A (2004) The role of communication and trust in explaining customer loyalty: An extension to the ECSI model. European Journal of Marketing 38: 1272-1293.

132.Zeithaml VA, Bitner MJ (1996) Services marketing. New York: McGraw-Hill.

133. Loureiro SMC, Kastenholz E (2011) Corporate reputation, satisfaction, delight and loyalty towards rural lodging units in Portugal. International Journal of Hospitality Management 30: 575-583.

134. Kim HR, Lee M, Lee HT, Kim NM (2010) Corporate social responsibility and employee company identification. Journal of Business Ethics 95: 557-569.

135. Chang HH, Wang YH, Yang WY (2009) The impact of e-service quality customer satisfaction and loyalty on e-marketing: Moderating effect of perceived value. Total Quality Management 20: 423-443.

136. Chun R (2005) Corporate Reputation: Meaning and Measurement. International Journal of Management Reviews 7: 91-109.

137. Selnes F (1998) Antecedents and consequences of trust and satisfaction in buyer-seller relationships. European Journal of Marketing 32: 305-322.

138. Chiou JS, Droge C (2006) Service quality, trust, specific asset investment, and expertise: Direct and indirect effects in a satisfaction-loyalty framework. Journal of the Academy of Marketing Science 34: 613-627.

139. Andreassen TW (1994) Satisfaction, Loyalty and Reputation as Indicators of Customer Orientation in the Public Sector. International Journal of Public Sector Management 7: 16-34.

140. Marzo-Navarro M, Pedraja-Iglesias M, Pilar Rivera-Torres M (2005) Measuring customer satisfaction in summer courses. Quality Assurance in Education 13 : 53-65.

141. Helgesen $\varnothing$, Nesset $E$ (2007) Images, satisfaction and antecedents: Drivers of student loyalty? Corporate Reputation Review 10: 38-59.

142. Kim MK, Park MC, Jeong DH (2004) The effects of customer satisfaction an switching barrier on customer loyalty in Korean mobile telecommunication services. Telecommunications Policy 28: 145-159.

143. Brunner TA, Markus S, Klaus O (2008) Satisfaction, Image and Loyalty: New Versus Experienced Customers. European Journal of Marketing 42: 10951105

144. Hoq MZ, Muslim AMIN (2010) The role of customer satisfaction to enhance customer loyalty. Reason 2: 139-154

145. Davies G, Chun R (2002) Gaps between the internal and external perceptions of the corporate brand. Corporate Reputation Review 5: 144-158.

146. Andreassen TW, Lindestad B (1998) The effect of corporate image in the formation of customer loyalty. Journal of Service Research 1: 82-92. 
147.Wu JHC, Lin YC, Hsu FS (2011) An empirical analysis of synthesizing the effects of service quality, perceived value, corporate image and customer satisfaction on behavioral intentions in the transport industry: A case of Taiwan high-speed rail. Innovative Marketing 7: 83-100.

148. Sirgy MJ, Samli AC (1989) The store loyalty concept: dimensions and measurement. Retail Marketing Strategy, New York.

149. Bloemer J, De Ruyter K (1998) On the relationship between store image, store satisfaction and store loyalty. European Journal of Marketing 32: 499-513.

150. Kandampully J, Suhartanto D (2000) Customer loyalty in the hotel industry: the role of customer satisfaction and image. International Journal of Contemporary Hospitality Management 12: 346-351.

151. Bigné JE, Sanchez MI, Sanchez J (2001) Tourism image, evaluation variables and after purchase behaviour: inter-relationship. Tourism Management 22 607-616.

152. Johnson MD, Gustafsson A, Andreassen TW, Lervik L, Cha J (2001) The evolution and future of national customer satisfaction index models. Journal of Economic Psychology 22: 217-245.

153. Kaur H, Soch H (2013) Mediating roles of commitment and corporate image in the formation of customer loyalty. Journal of Indian Business Research 5: 33-51.

154. Helm S (2007) One reputation or many? Comparing stakeholders' perceptions of corporate reputation. Corporate Communications: An International Journal 12: 238-254.

155.Akroush MN, Jraisat LE, Kurdieh DJ, Qatu LT (2016) Tourism service quality and destination loyalty the mediating role of destination image from international tourists' perspectives. Tourism Review 71: 18-44.

156. Riel CBM (2003) The management of corporate communication. In: Balmer JMT, Greyser SA editors. Revealing the corporation. London: Routledge, pp: 161-170.

157. Walsh G, Beatty SE, Shiu EMK (2009) The customer-based corporate reputation scale: Replication and short form. Journal of Business Research 62: 924-930.
158. Podsakoff PM, MacKenzie SB, Lee JY, Podsakoff NP (2003) Common method biases in behavioral research: $A$ critical review of the literature and recommended remedies. Journal of Applied Psychology 88: 879-903.

159. Podsakoff PM, Organ DW (1986) Self-reports in organizational research: Problems and prospects. Journal of Management 12: 531-544.

160. Hair JF (2007) Research Methods for Business, John Wiley \& Sons, Chichester, England.

161. Fornell C, Larcker DF (1981) Evaluating structural equation models with unobservable variables and measurement error. Journal Marketing Research 18: 39-50.

162. Shiu E, Pervan SJ, Bove LL, Beatty SE (2011) Reflections on discriminant validity: Re-examining the findings. Journal of Business Research 64: 497-500.

163. Forman J, Argenti PA (2005) Top of Mind How Corporate Communication Influences Strategy Implementation, Reputation and the Corporate Brand: An Exploratory Qualitative Study. Corporate Reputation Review 8: 245-264.

164.Abd-El-Salam EM, Shawky AY, El-Nahas T (2013) The impact of corporate image and reputation on service quality, customer satisfaction and customer loyalty: testing the mediating role. Journal of Business and Retail Management Research.

165. Obermiller C, Spangenberg ER, MacLachlan DL (2005) Ad skepticism: The consequences of disbelief. Journal of Advertising 34: 7-17.

166. Morhart F, Malär L, Guevremont A, Girardin F, Grohmann B (2015) Brand authenticity: An integrative framework and measurement scale. Journal of Consumer Psychology 25: 200-218.

167. Avram DO, Kühne S (2008) Implementing responsible business behavior from a strategic management perspective: Developing a framework for Austrian SMEs. Journal of Business Ethics 82: 463-475.

168. Moura-Leite R, Padgett R (2014) The effect of corporate social actions on organizational reputation. Management Research Review 37: 167-185. 